\title{
Evaluation of Just in Time Implementation and Total Quality Management Using Confirmatory Factor Analysis
}

\author{
Irawati Nursaningsih Magister Management Program \\ Mercu Buana University \\ Jakarta, Indonesia
}

\begin{abstract}
There are research gaps and phenomena that occur in the era of globalization need to be done research that aims to know and evaluate the implementation of Just in time (JIT) and Total Quality Management (TQM) using Confirmatory Factor Analysis (CFA). The research was conducted at PT. XYZ. Resources are obtained through field observations, interviews, documentation and questionnaires using a sample of 180 respondents. Data is obtained from primary and secondary data sources. According to the level of explanation including qualitative descriptive research. The analysis technique used is descriptive analysis using Confirmatory Factor Analysis (CFA). The results showed that PT. XYZ has implemented JIT and TQM only found a few obstacles. This research has implications on managerial policy and can be used by management in determining company policies to produce JIT and TQM which both CFA Test Results show the highest standardize estimated value exists in the flexible workforce dimension which is the right way especially in the JIT section and an important initial role before the implementation process where the main focus is employees. While the implementation of good TQM the highest standardize estimated value is in the respect for employee's dimension which is the right way especially in the TQM section.
\end{abstract}

Keywords:- Just in Time (JIT), Total Quality Management (TQM) and Confirmatory Factor Analysis (CFA) Test.

\section{INTRODUCTION}

The era of globalization of the development of manufacturing industry in Indonesia encountered huge industrial challenges. In addition to unstable national and international economic conditions, there are various challenges the manufacturing industry must face. The following are some of the main challenges in the manufacturing industry namely difficulty in predicting product demand, difficulty in controlling inventory, difficulty in improving efficiency in factories, difficulty in increasing ROI, lack of qualified labor, difficulty in managing sales prospects and confusion at the emergence of new technologies (Rishna Maulina, 2019).

Changes in the business environment trigger each company to rethink other efforts or businesses that it feels will be able to increase productivity (financial or capital, labor, products, organization, sales and production),

\author{
Niken Sulistyowati Magister Management Program \\ Mercu Buana University \\ Jakarta, Indonesia
}

efficiency, quality, effectiveness, timeliness and service delivery that is expected to increase the company's competitive advantage so that it can survive and be able to compete in the global market. Companies live in fastchanging, dynamic and complicated environments. The rapid development in the industrial sector today results in more and more levels of competition faced by each company in achieving the company's goals. In order to compete in the market each company will strive to outperform each other, this is sought to make the most profit (Diaz and Retnani, 2015 in Marida suneth, 2016).

This is supported by a study conducted by Linda Santioso and Cynthia Maharani, 2015 stating that variable total quality management and just in time have an influence on delivery performance variables. The results of this study also show that the implementation of total quality management and just in time are two interconnected elements and if a company can apply total quality management and just in time simultaneously then it will be able to improve the delivery performance of the company so that with the improvement of delivery performance then the company can improve its quality optimally.

In this study there is a research gap from previous research. Ferdinand's opinion, (2014), research gap is the formulation of research problems stemming from gap phenomena or business phenomena, according to field data, research gap and gap theory. Some research studies are: 1) There are differences in the instruments used, where in previous research used instruments developed by Muhammad Rafiq (2017) that explain the application of just in time only with descriptive analysis. Evaluation of just in time implementation based on key elements just in time developed by Simamora (2012) using descriptive analysis with confirmatory factor analysis (CFA) analysis. 2) There are differences in research conducted by Marida Suneth (2016), on the application of just in time system in improving the productivity of the company in PT. Create Sinar Perkasa Concrete in Makassar. There are differences of view regarding the implementation of just in time purchasing system. In this study there are empirical gaps and methodological gaps. This time, researchers conducted research in the field of electrical manufacturing industry in 2020 (Population Gap). 3) Previous research conducted research on manufacturing companies located in Makasar while this research used the objects of manufacturing companies located in Jakarta (Population Gap). 4) The 
previous research was conducted in 2016, while in this study was conducted in 2020 (timing gap).

Based on the background description, can be identified the problems that occur are: the phenomena that occur in PT. XYZ such as: production order value profile to production realization is still not able to fulfill production order $(82.2 \%)$, gap in production yield achievement below $100 \%$ under the plan set, loss cost process condition is still high, defect ratio $0.764 \%$, there is a previous research gap against the variables used, methodology and analysis used. Based on the above background, the problems that can be formulated in this study are as follows: 1) How to implement just in time (JIT) using confirmatory factor analysis (CFA) in PT. XXZ? And 2) How to implement total quality management (TQM) using confirmatory factor analysis (CFA) in PT. XYZ?

Taking into account the cost, time and number of factors that can influence the results of research, this research was conducted in PT. XYZ and restricts the group of respondents. The respondents selected are a group of employees at PT. XYZ part of the water pump unit business, this aims to make this research more focused on related objects that are the subject matter. The purpose of this research is to know and evaluate the implementation of just in time (JIT) and total quality management (TQM) using confirmatory factor analysis (CFA) at PT. XYZ. This research is expected to provide benefits and scientific contributions in the world of education is expected to increase insight and develop the application of the application of just in time (JIT) and total quality management (TQM) to the company's performance and literature reference. For companies and practitioners are expected to provide input to PT. XYZ deals with issues that occur with the right TQM and JIT approaches so as to drive the realization of continuous improvement in the company's performance.

\section{THEORITICAL REVIEW}

\section{A. Just In Time(JIT)}

In short, just in time is an approach that seeks to eliminate all sources of waste, something that does not add value in the production activities by injecting the right parts at the right place and time. (Schroeder, 1994 in Marida Suneth, 2016). Santioso and Maharani (2015) stated that just in time is a model in which the company only produces on the basis of demand without utilizing the availability of supplies and without bearing the cost of inventory. According to Henry Simamora (2012) the elements that can determine the success of just in time and can reduce waste are: limited number of suppliers, minimal inventory level, and factory layout improvement, reduction of maintenance period, integrated quality control and flexible workforce.
Based on the above description, the just in time indicators presented are a limited number of suppliers, minimal inventory levels, factory layout improvement, reduced maintenance period, integrated quality control and flexible workforce. JIT is a management concept focused on implementing the production process without any waste through simplification of the production process. Instruments used in the JIT use key element instruments developed by Simamora. In this study, the JIT variable consisted of 6 (six) dimensions.

\section{B. Total Quality Management (TQM)}

Ellitan (2002) in Fannie (2005) explained that total quality management is performance optimization in all parts and functions of operations, procedures, control systems, organizational structures and cultures. The implementation of TQM provides positive results in improving productivity, profitability and overall performance. Mc. Closkey and Collett (1993) in Wardhani (2001) explained that TQM is a concept that emphasizes on consumer satisfaction manifested in the activities of producing superior products, the best service, and the ability to adjust quickly to changing consumer needs. This concept focuses on the commitment of all members of the organization to quality improvement in all aspects of the company's management. According to Nasution (2005:30) there are four main principles in Total Quality Management (TQM), namely: customer satisfaction, respect for employees, management based on facts and continuous improvement.

The first research by Sik Sumaedi and Medi Yarmen, 2015 describes the understanding of ISO 9001. ISO 9001 is an international standard of quality management system issued by ISO. This standard is the most widely adopted ISO standard by organizations around the world. The standard was first published in 1987 and then revised in 1994, 2000, and 2008. ISO 9001 consists of quality management system best practices that are expected to deliver significant results if standards are implemented consistently. In the standard stipulated that ISO 9001 aims to ensure organizations to produce products according to customer needs achieve customer satisfaction and achieve continuous improvement in the effectiveness of their quality management systems. Since the standard version of 2000 , ISO 9001 integrates the principles of total quality management into standards and focuses more on process and performance than documentation. In addition, ISO 9001 also adopts the PDCA (Plan Do Check Act) methodology.

According to Fitrihana (batikyogya.wordpress.com) said, there are eight quality management principles in the ISO 9001:2000 quality management system used to lead the organization towards performance improvement. The principles are: customer focus, leadership, Involvement of People, process Approach, system approach to management, continual improvement, factual approach to decision making and mutually beneficial supplier relationship. 


\section{Thinking Framework}

Research framework model has variables consisting of Just in Time (JIT) and Total Quality Management (TQM).

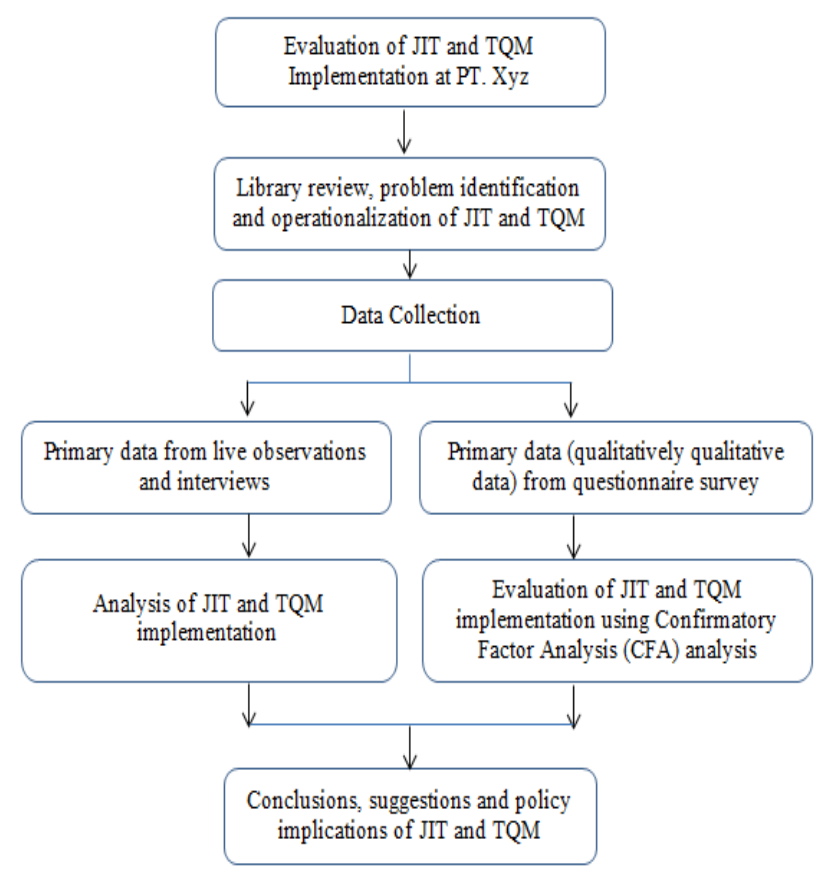

Fig 1:- Research Framework

(Source: Ferdinand, Augusty, 2014)

Figure 1 shows the research frame of thought starting with title determination, library review and just in time operationalization and total quality management, data collection from primary data from live observation and interviews, and primary data (qualitative data qualitatively qualitative data) from questionnaire survey, analysis of JIT and TQM implementation, evaluation of JIT and TQM implementation using Confirmatory Factor Analysis (CFA) analysis, last obtained conclusions, advice and policy implications just in time and total quality management at PT. XYZ.

This research shows in this study there are latent variables namely TQM and JIT. Variable TQM consists of 7 (seven) indicators and variable JIT consists of 6(six) indicators. TQM has seven (7) dimensions namely focus customer, leadership, respect for employees, relations with suppliers, employee education and training, process improvement and decision making. The focus customer dimensions are divided into 3 indicators $(\mathrm{CF} 1, \mathrm{CF} 2$ and CF3). Leadership dimensions are divided into 3 indicators (LD1, LD2, and LD 3). The dimensions of respect for employees are divided into 3 indicators (RE1, RE2 and RE3). The dimensions of relations with suppliers are divided into 3 indicators (RS1, RS2 and RS3). Dimensions of employee education and training become 2 indicators (ET1 and ET2). Process Improvement dimensions are divided into 3 indicators (PI1, PI2 and PI3). The dimensions of decision making are divided into 3 indicators (DM1, DM2 and DM3). TQM is expected to provide a value of significance (must be below 0.05) and the standardized estimate value should be above 0.5 ( Haryono,
2017). Just in time has seven dimensions (6) dimensions namely limited number of suppliers, minimum inventory, improvement of factory layout, setup time reduction, integrated quality control, flexible workforce. The dimensions of the limited number of suppliers are divided into 2 indicators (LS1 and LS2). The minimum inventory dimensions are divided into 3 indicators (MI, MI2 and MI3). The dimensions of improvement of factory layout are divided into 3 indicators (IL1 and IL3). The setup time reduction dimension is divided into 3 indicators (SR1, SR2 and SR3). The dimensions of integrated quality control are divided into 3 indicators (IQ1 and IQ2). Flexible workforce dimensions are divided into 3 indicators (FW1, FW2 and FW3). JIT is expected to provide its significance value (must be below 0.05) and the standardized estimate value should be above 0.5 ( Haryono, 2017).

Based on the above research framework, it is expected that JIT and TQM can provide a value of significance (must be below 0.05 ) and the standardized estimate value should be above 0.5 (Haryono, 2017). Variable JIT consists of 6(six) indicators and variable TQM consists of 7(seven) indicators, determining the highest standardize estimated value on the JIT indicator, determining the highest standardize estimated value on the TQM indicator. Finally came the conclusions, suggestions and policy implications just in time (JIT) and total quality management (TQM) at PT. XYZ.

\section{METHODOLOGY}

The sources of information in this study are obtained through questionnaires, interviews and observations as well as primary and secondary data that are in the company and relevant to the research. The number of samples taken was 180 respondents. The observed variables are concerning JIT and TQM. The analysis unit in this study is the view of employees at PT. XYZ on the application of JIT and TQM variables studied. The population in this study is an employee of the company in PT. XYZ, sampling is included in the non-probability sampling category with purposive sampling techniques that are people who are related and or involved in JIT and TQM activities. The research phase starts from title determination, library study, problem identification and operationalization, data collection (observation, interview and evaluation), descriptive analysis, processing and testing of data and finally obtained conclusions, suggestions and policy implications of JIT and TQM. Testing data in this study includes confirmatory factor analysis (CFA) Test, average variance extracted and construct reliability.

\section{RESEARCH RESULT}

\section{A. Evaluation of JIT implementation}

Business processes in the water pump unit business ranging from ordering raw materials to becoming finished products that will be distributed to dealers. The process is described as following : 


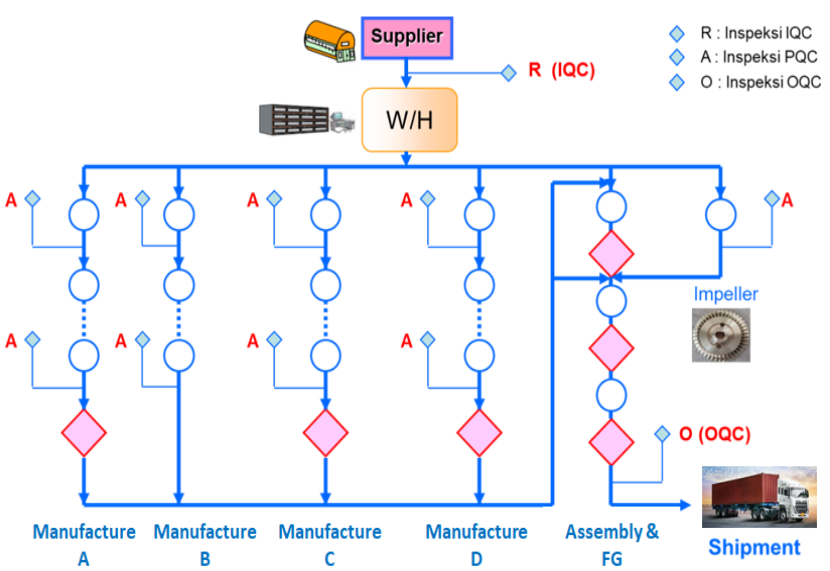

Fig 2:- Business Unit Flow at PT. XYZ

(Source : Data PT. XYZ, 2020)

Figure 2 explains that the first business process flow is that the sales company delivers the number of product orders needed to the PPC division. Then the PPC division made production scheduling to be handed over to the purchasing division. Then the purchasing division orders raw materials to suppliers who then the new supplier will deliver the raw materials and will be directly handled by IQC who have the task to always control the incoming raw materials before processing in the production department. After the raw material passes the check from IQC,then the raw material is placed in the warehouse storage of raw materials, then handed over to the production section to be produced immediately based on the number of production plans. After going through the production process, the material will again be checked by the PQC division to see if any material has defected or not before it is submitted to the finishing process. After the PQC declares the part passed the check, the material is taken to the finishing process then to the final assembly process to be assembled into a product.
The next process is to check the finished goods product by the OQC division, which is the division that will inspect the product before distribution. After OQC stated the product passed the check, then the product was taken to warehouse finish good as a place of storage of finished goods before distribution.

Based on the results of direct observations in the field, interviews and studies literature, researchers evaluate the implementation of just in time; researchers will discuss how the elements of the application element just in time are applied in PT. XYZ. Evaluation of implementation just in time at PT. XYZ requires an overview of the production process currently implemented by the company using the terms contained in the production process just in time. As already known in the previous section, PT. XYZ water pump unit business produces household appliances.

According to Henry Simamora (2012) elements that can determine the success of just in time and can reduce waste applied by PT. XYZ is as follows: limited number of suppliers, minimum inventory, improvement of factory layout, reduction setup time, integrated quality control and flexible workforce.

PT. XYZ implements a just in time method of determining the number of major suppliers with a sufficiently close location and already has criteria for suppliers in determining the materials needed. PT. XYZ implements a just in time method of managing material procurement due to the location of the main supplier which is quite close. However, in the concept of just in time the purchase of imported materials, PT. XYZ still finds little constraint due to weather factors.

\begin{tabular}{|c|c|c|c|c|}
\hline Dimensions & $\begin{array}{c}\text { JIT } \\
\text { Implementation }\end{array}$ & $\begin{array}{l}\text { Conditions in } \\
\text { PT. XYZ }\end{array}$ & $\begin{array}{c}\text { Constraints and } \\
\text { Prevention by PT. XYZ }\end{array}$ & $\begin{array}{l}\text { JIT Implementation Evasion } \\
\text { Results }\end{array}$ \\
\hline \multirow[t]{2}{*}{$\begin{array}{l}\text { Limited number } \\
\text { of suppliers }\end{array}$} & $\begin{array}{l}\text { Screening of } \\
\text { suppliers }\end{array}$ & $\begin{array}{c}\text { Suppliers selection } \\
\text {-Only suppliers that meet } \\
\text { the standards can } \\
\text { cooperate with PT. XYZ, } \\
\text { a supplier considereda } \\
\text { business partner } \\
\text { - Material is not difficult } \\
\text { to obtain, because it } \\
\text { comes from local material } \\
\text { with close proximity. }\end{array}$ & $\begin{array}{l}\text { Materials derived from } \\
\text { import are sometimes } \\
\text { constrained by delays in } \\
\text { arrival time due to } \\
\text { weather conditions and } \\
\text { too long lead time } \\
\text { delivery. } \\
\text { Prevention : Material } \\
\text { change from import } \\
\text { supplier to local and } \\
\text { model change }\end{array}$ & \multirow{2}{*}{$\begin{array}{l}\text { PT. XYZ has implemented a } \\
\text { just in time method in } \\
\text { determining the number of } \\
\text { major suppliers with a } \\
\text { sufficiently close location } \\
\text { and already has criteria for } \\
\text { suppliers in determining the } \\
\text { raw needed. Pt. XYZ has } \\
\text { implemented a just in time } \\
\text { method in managing raw } \\
\text { material procurement due to } \\
\text { the location of the main } \\
\text { suppliers which is quite } \\
\text { close. However, in the } \\
\text { concept of just in time the } \\
\text { purchase of imported } \\
\text { material. PT. XYZ still finds } \\
\text { little constraint due to } \\
\text { weather factors. }\end{array}$} \\
\hline & $\begin{array}{c}\text { The selected } \\
\text { supplier is a } \\
\text { quality certified } \\
\text { supplier }\end{array}$ & $\begin{array}{c}\text { The selected supplier is a } \\
\text { supplier who has a quality } \\
\text { certificate. } \\
\text {-Conduct regular audits } \\
\text { suppliers } \\
\text {-Materials purchased by } \\
\text { necessity only } \\
\text {-No over stock }\end{array}$ & $\begin{array}{l}\text { There are still complaints } \\
\text { about quality that is not } \\
\text { standard. prevention: PT. } \\
\text { XYZ not only provides } \\
\text { complaints to suppliers, } \\
\text { but help and support } \\
\text { machines and tools. }\end{array}$ & \\
\hline
\end{tabular}

Table 1:- Observation result of Limited number of suppliers

(Source : PT. XYZ, 2020) 
Based on table 1 above, that after the researcher did the evaluation, stated that PT. XYZ is still consistent in the implementation of just in time especially against suppliers have qualified for success just in time. This is in accordance with the opinion of Henry Simamora (2012) the elements that can determine the success of just in time are the limited number of suppliers. In a timely system, suppliers are treated as partners and are usually associated with long contracts with the company. But the evaluation results show there are still a few problems with suppliers namely: imported goods are sometimes constrained by delays in arrival due to weather conditions and there are still complaints against quality that are not standard. However, despite the above constraints, PT. XYZ takes steps to improve and prevent with suppliers, so that the implementation of just in time is still consistently implemented.

PT. XYZ implements a just in time method in determining the minimum inventory. In this case, raw materials and spare parts are purchased and received only when needed, producing manufacturing products, distribution is made based on packing standards and lead time, the final assembly inventory products are made one by one or known as one piece flow and use kanban cards. However, in the concept of Just in Time minimum inventory, PT. XYZ still finds inventory constraints for imported materials and standard packing, zero inventories can only be applied to finished products, while for materials and WIP (work in process) has not fully reached zero inventories.

\begin{tabular}{|c|c|c|c|c|}
\hline Dimensions & JIT Implementation & $\begin{array}{l}\text { Conditions in } \\
\text { PT. XYZ }\end{array}$ & $\begin{array}{c}\text { Constraints and } \\
\text { Prevention by PT. XYZ }\end{array}$ & $\begin{array}{l}\text { JIT Implementation Evasion } \\
\text { Results }\end{array}$ \\
\hline \multirow[t]{3}{*}{$\begin{array}{l}\text { Minimum } \\
\text { Inventory }\end{array}$} & $\begin{array}{c}\text { Make a purchase } \\
\text { when there is an order }\end{array}$ & $\begin{array}{l}\text { Raw materials and } \\
\text { parts are purchased } \\
\text { and accepted only } \\
\text { when needed }\end{array}$ & $\begin{array}{l}\text {-Supplies for imported } \\
\text { materials are difficult to } \\
\text { minimize due to weather } \\
\text { factors } \\
\text {-Packing standards for } \\
\text { certain materials such as } \\
\text { screw bolts, terminal } \\
\text { covers, black vans, still } \\
\text { not minimized packing } \\
\text { standards }\end{array}$ & \multirow{3}{*}{$\begin{array}{l}\text { PT. XYZ has implemented a just } \\
\text { in time method in determining } \\
\text { the minimum inventory. In this } \\
\text { case PT. XYZ Raw materials and } \\
\text { parts are purchased and accepted } \\
\text { only when needed, manufacture } \\
\text { manufacturing products, } \\
\text { distributions are made based on } \\
\text { packing and lead time standards, } \\
\text { final assembly inventory } \\
\text { products are made } 1 \text { by one or } \\
\text { known as one piece flow and use } \\
\text { kanban cards. PT. XYZ has the } \\
\text { opportunity to implement just in } \\
\text { time methods in managing } \\
\text { minimum inventory. However, in } \\
\text { the concept of Just In Time } \\
\text { minimum inventory, pt company. } \\
\text { XYZ still finds inventory } \\
\text { constraints for imported } \\
\text { materials and packing standards, } \\
\text { zero inventory can only be } \\
\text { applied to finished products, } \\
\text { while for materials and WIP has } \\
\text { not fully reached zero inventory. }\end{array}$} \\
\hline & $\begin{array}{l}\text { Raw materials } \\
\text { produced must not be } \\
\text { more than ordered }\end{array}$ & $\begin{array}{l}\text { Pt. XYZ in producing } \\
\text { manufacturing } \\
\text { products, distribution } \\
\text { is made based on } \\
\text { packing standards and } \\
\text { lead time, while for } \\
\text { final assembly } \\
\text { products inventory is } \\
\text { made } 1 \text { per } 1 \text { or } \\
\text { known as one piece } \\
\text { flow. } \\
\text { - PT. XYZ, using } \\
\text { Kanban Card }\end{array}$ & $\begin{array}{l}\text { zero inventory can only } \\
\text { be applied to finish good } \\
\text { or finished products, } \\
\text { while for raw material } \\
\text { and WIP has not fully } \\
\text { reached zero inventory }\end{array}$ & \\
\hline & $\begin{array}{l}\text { No buffer items in the } \\
\text { warehouse }\end{array}$ & $\begin{array}{l}\text { Finish good can be } \\
\text { attempted zero } \\
\text { inventory condition. }\end{array}$ & & \\
\hline
\end{tabular}

Table 2:- Observation result of Minimum Inventory

(Source : PT. XYZ, 2020)

From the explanation of Table 2 above, after the researcher conducts the evaluation, states that PT. XYZ implementation has been just in time especially against the minimum inventory level has qualified the requirements of success just in time. In a just in time environment,raw materials and parts are purchased and accepted only when needed. The evaluation results show there are still a few constraints with a minimal level of inventory namely: inventory for imported materials is difficult to minimize because weather factors and packing standards for certain raw materials have not been minimized standard packingnya. Although there are the above constraints, PT. $\mathrm{XYZ}$ continues to negotiate with suppliers, to reduce packing standards so that the implementation of just in time remains consistently implemented.

PT. XYZ implements the Just in Time method in determining the Improvement of factory layout. In this case PT. XYZ implements Just In Time method in managing Improvement of factory layout because material transport uses trolley with standard packing, use of kanban card and Material Picking Slip (MPS) card, lay out final assembly, using next cell, one piece flow, manufacture machines 2 meters away, Final assembly lay out distance between operators 1 to other operators 0.5 meters. Manufacture machines with layouts 2 meters away. However, in the 
concept of Just In Time in Improvement of factory layout, PT. XYZ still finds constraints on the assembly layout because the lay out rotor is located in building 1, in contrast to the lay out stator and final assembly located in building 2, so it experiences constraints of distance and time to supply to the line, consequently necessary supplies to avoid material delays.

PT. XYZ implements the Just in Time method in determining set-up time reduction. In this case PT. XYZ implements the Just in Time method of managing PT set-up time reduction. XYZ by the way before the production process is carried out, all materials, machines, methods and manpower have been confirmed. In charge of ensuring $4 \mathrm{M}$ and filling in the $4 \mathrm{M}$ check sheet before production begins. Only critical process can be carried out by the operator itself, while for the set-up of critical process machines, the safety process must be carried out by the responder, training the set-up of the machine periodically, the machine is set-up using a time that has been 15 minutes. However, in the concept of Just In Time against Set-up time reduction, PT. $\mathrm{XYZ}$ still finds obstacles still found sudden change of model, this is due to: materials and machines that impact production achievement does not reach $100 \%$ and production productivity condition is still below target. However PT. XYZ continues to make improvements to address the above issues by strictly controlling the arrival of materials. Problems of damaged machines are carried out repairs by performing the process of dissolving production tools, in a manner that includes cleaning seiso machine and $5 \mathrm{~S}$ check.

PT. XYZ implements the Just in Time method of managing integrated quality control by performing process capabilities, process statistical control and continuous improvement. The quality control process is prefix with the inspection of material arrival from suppliers. It must be ensured that the responsibility of the supplier conducts a preliminary inspection, so that the quality of the materials sent to PT. XYZ can be guaranteed. Production part employees must be responsible for the resulting product. However PT. XYZ still finds problems encountered some defect processes such as wire disconnects and motor noise caused by errors in 4M. PT. XYZ continues to make improvements to address the problem by conducting integrated quality control, by forming a quality control group or known as QCC (Quality Control Cycle).

PT. XYZ already implements the Just in Time method in flexible workforce. Factory layout PT. XYZ in a Just in Time environment demands that employees have to master a variety of technical skills. In just in time work environment, an employee of PT. XYZ is required to operate several types of machines simultaneously. In addition, because Just in Time requires employees to produce only what the next work station needs, then when the needs have been met, the employees in the manufacturing cell are expected to perform minor repairs and maintenance tasks to the machine equipment in the manufacturing cell. PT. XYZ not only has 1 process skill, they have more than 3 process skills In addition, and employees are also given repair training, machine maintenance and are displayed in product dimensioning. If it has been declared a pass, it will be certified according to their respective skills. Certification in the form of the issued ability card. Because of the system all training processes are carried out in a systematic way so that there are no constraints in terms of the skills of workforce PT. XYZ because it has a flexible workforce.

With the implementation of JIT in PT. XYZ has its advantages and disadvantages as seen in Table 3:

\begin{tabular}{|c|c|c|}
\hline No & Advantages & Disadvantages \\
\hline 1 & $\begin{array}{c}\text { Eliminating waste } \\
\text {-Production run plan on demand only } \\
\text {-No over process in final assembly } \\
\text {-Manufacturing producing the necessary goods only }\end{array}$ & $\begin{array}{l}\text { The Company has difficulty producing only according to } \\
\text { customer orders: } \\
\text {-If there are additional orders, then PT. XYZ will be } \\
\text { difficult to meet these requests }\end{array}$ \\
\hline 2 & $\begin{array}{c}\text { Small inventory, maybe zero } \\
\text {-FG final assembly zero inventory } \\
\text {-WIP final assembly according to lead time only }\end{array}$ & $\begin{array}{c}\text { Putting employees on one type of product is not easy } \\
\text {-If there are assembly employees who do not enter, then } \\
\text { manufacturing employees will difficult help because they } \\
\text { do not have excess capacity } \\
\text {-Different skills. }\end{array}$ \\
\hline 3 & $\begin{array}{l}\text { Factory layout grouped cell system } \\
\text {-Layout using next cell system and one piece flow }\end{array}$ & $\begin{array}{c}\text { Takes a lot of time building relationships with suppliers } \\
\text {-More negotiations are needed, so it takes time } \\
\text { - There's swelling of costs. }\end{array}$ \\
\hline 4 & $\begin{array}{c}\text { Employee grouping on one product type } \\
\text {-Employees divided into } 2 \text { parts, manufacturing and } \\
\text { assembly }\end{array}$ & \\
\hline 5 & $\begin{array}{c}\text { Employee empowerment in accordance with changes in } \\
\text { tools and working methods } \\
\text {-There is always the idea of improvement ideas and } \\
\text { innovations for productivity improvement. }\end{array}$ & \\
\hline 6 & $\begin{array}{c}\text { Total quality control } \\
\text { - Reduction of loss cost and defect in each part decreases. }\end{array}$ & \\
\hline
\end{tabular}

Table 3:- The advantages and disadvantages of just in time implementation at PT. XYZ 


\section{B. Evaluation of TQM implementation}

Evaluation of the implementation of total quality management in PT. XYZ needs to be done to know the picture of the production process currently implemented by the company using the terms contained in total quality management. Nasution (2005) explains that total quality management (TQM) is an approach in running a business that tries to maximize the competitiveness of the organization through continuous improvement of its products, services, workforce, processes and environment. Total quality management variables are measured by selfdeveloped instruments with the quality criteria contained in ISO 9001. In this study, the principle of quality management in iso 9001:2000 quality management system used to evaluate the implementation of total quality management in PT. XYZ as follows: customer focus, leadership, respect for employees, process approach and employee education and training, continual improvement (continuous improvement), factual approach to decision making (fact-based decision making) and mutually beneficial supplier relationship

PT. XYZ prioritizes the role of customers in providing feedback or input to pump products. Customers provide input in the design of water pump products and conduct consumer satisfaction evaluations. Activities by PT. XYZ in this case is conducting product surveys and market surveys, providing service centers in several locations such as in Jakarta and Bogor areas. Provide spare parts that are easy to find in electronic outlets. In addition, PT. XYZ conducts exhibitions and art seminars to give an in-depth introduction of products to its customers. PT. XYZ formed a special team that was coordinated by the quality assurance (QA) section to collect feedback information from customers, both external and internal customers. A formal survey of external customers' needs to be carried out every. From the explanation above, after researchers evaluated the quality criteria of customer focus (focus on customers), stated that PT. XYZ is consistent in implementing the implementation of total quality management especially towards customer focus and has fulfilled the principle of quality management in iso 9001:2000 quality management system. This is in accordance with Nasution opinion (2005) explaining, that total quality management (TQM) is an approach in running a business that tries to maximize the competitiveness of the organization through continuous improvement of its products, services, workforce, processes and environment. TQM variables are measured by self-developed instruments with the quality criteria contained in ISO 9001.

Leader of PT. XYZ is tasked with building a unity of goals and directing the organization in achieving that goal. Organization leaders at PT. XYZ establish and maintain its internal corporate environment where people can be overall involved in achieving the company's goals. Every end of the year, the leader of PT. XYZ invites the involvement of its part leaders to carry out business plans and strategies that will be pursued to achieve the target stipulated. To coordinate all activities in PT. XYZ always has regular daily, weekly and monthly meetings. It aims to provide understanding and motivation through organizational goals and objectives to its employees, evaluating activities, straightening, and implementing with complexity, reducing and avoiding miscommunication between organizational levels. From the above explanation, after the researcher evaluated the leadership, stated that PT. XYZ is consistent in the implementation of total quality management, especially towards leadership, has fulfilled the principle of quality management in the ISO 9001:2000 quality management system.

Respect for employees, quality assurance (QA) periodically monitors employee attitudes and satisfaction. This can be done by holding a formal survey every year. QA and other managers need to be in close contact with employees so that they can get accurate information about their attitude and satisfaction. This information is also necessary to evaluate the progress achieved and determine the necessary corrective actions. Full involvement of PT. $\mathrm{XYZ}$ is much needed for the company, because with the capabilities of each employee, it can provide benefits for the company. PT. XYZ activates and engages all employees/people within the organization, innovating and creativity in the company's goals. Employees of PT. XYZ are more responsible for its performance and employees will participate and contribute to continuous improvement. From the explanation above, after researchers evaluated the involvement of people (the involvement of all employees) stated that PT. XYZ is consistent in the implementation of total quality management especially towards the involvement of people (the involvement of all employees and has fulfilled the principles of quality management in the ISO 9001:2000 quality management system.

PT. XYZ approaches the process, which means that the company's activities and related resources are managed as a process, so the desired results can be achieved more efficiently. PT. XYZ reduces costs and shortens cycle time through effective use of resources. The approach of this process will increase results, be consistent and predictable and the opportunity for improvement becomes priority and focused. In this case PT. XYZ also conducts training for employees to improve the quality of products and opportunities to pursue formal and informal education. From the explanation above, after the researchers evaluated the Employee education and training stated that PT. XYZ is consistent in the implementation of Total Quality Management especially towards employee education and training has fulfilled the principles of quality management in iso 9001:2000 quality management system.

PT. XYZ conducts continuous improvement and training at every step of the work process, using an information system for each process. If one of the machines stops operating, the operator is switched to the other machine so that the operator is not idle. Every quarterly, PT. $\mathrm{XYZ}$ is continual improvement both in terms of productivity and quality. Productivity improvements need to be made, given the $7 \%$ annual wage increase. Each section conducts improvement activities in order to achieve the target stipulated. This aims to reduce direct labor cost in order to achieve productivity improvement and loss reduction targets. Detailed evaluation of TQM implementation of 
continual improvement (continuous improvement) in PT. XYZ. Researchers evaluated continual improvement (continuous improvement) stated that PT. XYZ implements total quality management especially towards continual improvement and has fulfilled the principle of quality management in iso 9001:2000 quality management system.

\begin{tabular}{|c|c|c|}
\hline No & Name of Project & $\begin{array}{c}\text { Theme of Improvement } \\
\text { Project }\end{array}$ \\
\hline 1 & $\begin{array}{c}\text { Productivity up in } \\
\text { Assembly section }\end{array}$ & $\begin{array}{c}10 \% \text { productivity increase } \\
\text { by improving working } \\
\text { methods and 4M }\end{array}$ \\
\hline 2 & $\begin{array}{c}\text { Productivity up in } \\
\text { Assembly section }\end{array}$ & $\begin{array}{c}7 \% \text { productivity increase } \\
\text { by means of Reduced } \\
\text { people }\end{array}$ \\
\hline 4 & $\begin{array}{c}\text { Productivity up in } \\
\text { Assembly section }\end{array}$ & $\begin{array}{c}10 \% \text { productivity increase } \\
\text { by merging processes and } \\
\text { reducing over time. }\end{array}$ \\
\hline $\begin{array}{c}\text { Manufacturing machine } \\
\text { efficiency up }\end{array}$ & $\begin{array}{c}\text { Reduce loss time 10\% } \\
\text { when change model and } \\
\text { machine efficacy up }\end{array}$ \\
\hline
\end{tabular}

Table 4:- Project improvement activities at PT. XYZ

Table 4 above shown, after the researcher evaluated the continual improvement, it was stated that PT. XYZ implements total quality management, especially for continual improvement and has met the quality management principles in the ISO 9001: 2000 quality management system.

Factual Approach to Decision Making (fact-based decision making) of PT. XYZ in making effective decisions based on data and information analysis. The steps used in the application of this principle are: testing and collecting targeted data and information, ensuring data and information are accurate, trustworthy, and accessible, analyzing data and information using the correct methods, understanding the use of statistical techniques and following up on every decision in accordance with analysis and overnighting. Effective decision of PT. XYZ is a decision-making made based on the analysis of data and information. Therefore, in the company requires a factual approach in decision making to reduce the error in decision making.

PT. XYZ and suppliers or suppliers are inter dependent and should be a mutually beneficial relationship in order to improve the ability of both to create value. The implementation of this principle is: engaging suppliers in identifying the needs of PT. XYZ, involving suppliers in the process of developing PT strategy. XYZ ensures that the output from the supplier complies with the requirements of PT. XYZ and communicates and share information with suppliers. Supplier involvement in identifying needs in PT. $\mathrm{XYZ}$ always calls suppliers to hold meetings every month, in order to meet material needs, in addition to negotiating in order to cost reduction that is mutually beneficial to both parties.
Organization of PT. XYZ and suppliers or suppliers are inter dependent and should be a mutually beneficial relationship in order to improve the ability of both to create value. The implementation of this principle is: involve suppliers in identifying the needs of PT. XYZ, involve suppliers in the process of developing PT. XYZ strategy, ensure that the output from the supplier complies with the requirements of PT. XYZ and communicate and share information with suppliers. Supplier involvement in identifying needs in PT. XYZ always calls suppliers to hold meetings every month, in order to meet material needs, in addition to negotiating in order to cost reduction that is mutually beneficial to both parties. PT. XYZ engages suppliers in the process of developing PT. XYZ strategy by doing improvements be it material design or accompaniment and packaging strategy. Pt. XYZ always communicates and shares information with suppliers whether it is about material ordering information,complaint information be it delays or quality problems. PT. XYZ already uses SAP system in making witness contracts with suppliers. With the system will speed up the ordering system and reduce leadtime constraints,in addition stock conditions will continue to be monitored. This SAP information system, will facilitate communication between suppliers and PT. XYZ.

The researchers also observed several things, including: activities carried out by the Warehouse Department when receiving goods, the process of what activities are carried out when wanting to enter quality check for recently received goods, the process of laying materials that have been declared to pass IQC back in the warehouse, the process of preparing materials for production purposes based on material picking slips (MPS) as well as filling out a document form purchase requisition at the time the purchasing department wants to submit materials that need to be purchased for the purposes of the production department. The material to be supplyed to the produski uses a pull or pull system. So only the material that will be produced at that time will be given to the produlsi so that there is no buildup of inventory. At the beginning of the observation, the researchers looked at the working situation in the warehouse department,such as the storage and preparation of goods in the warehouse, all goods have been arranged based on indications, standard packing and equipped stock cards of each material and receipt of goods that have just reached the warehouse, and then researchers observed the availability of raw materials in the warehouse.

Pt. XYZ in conducting business activities, the company should pay attention to its relationship with suppliers. Companies and suppliers have the principle of interdependence and profitable relationships to increase the value of both. By applying the principle of mutually beneficial supplier relationships, the company will benefit from increasing the ability to create value for both parties, flexibility and speed of joint response to market changes or customer needs and desires and optimization of costs and resources. 
From the explanation above, after researchers saw mutually beneficial supplier relationship, shown that PT. $\mathrm{XYZ}$ implements a factual approach to decision making especially towards mutually beneficial supplier relationship has fulfilled the principle of quality management in iso 9001:2000 quality management system. This is in accordance with nasution opinion (2005) explaining, that total quality management (TQM) is an approach in running a business that tries to maximise the competitiveness of the organization through continuous improvement of its products, services, workforce, processes and environment. Total quality management variables are measured by selfdeveloped instruments with the quality criteria contained in ISO 9001.

With the implementation of TQM in PT. XYZ has its advantages and disadvantages as seen in Table 5:

\begin{tabular}{|c|c|c|}
\hline No & Advantages & Disadvantages \\
\hline 1 & $\begin{array}{c}\text { PT. XYZ meets customer satisfaction: prioritizes the role of } \\
\text { customers in providing pump product feedback and } \\
\text { conducting product surveys and market surveys, providing } \\
\text { service locations such as in Jakarta and Bogor areas }\end{array}$ & $\begin{array}{c}\text { Quality is often a side activity, separate from the key } \\
\text { issues of business strategy and performance: } \\
\text { Sometimes the department certainly assumes quality is } \\
\text { the responsibility of the QC only. }\end{array}$ \\
\hline 2 & $\begin{array}{c}\text { Cost reduction: loose cost reduction project and defect ratio } \\
\text { reduction project }\end{array}$ & $\begin{array}{c}\text { Quality does not have the same limits and meanings for } \\
\text { everyone, so there can be differences in how quality is } \\
\text { meant between people. }\end{array}$ \\
\hline 3 & Increase productivity 7\%. & $\begin{array}{c}\text { TQM is an activity that is only within departments in } \\
\text { many companies. }\end{array}$ \\
\hline 4 & Increase market share growth: seminars and product \\
exhibitions & $\begin{array}{c}\text { Each department has its own policies, so it does not cover } \\
\text { the entire organization. }\end{array}$ \\
\hline 5 & Time efficiency : defect reduction project & \\
\hline 7 & Employee empowerment: employees are directly involved \\
enith product surveys & \\
\hline
\end{tabular}

Table 5:- The advantages and disadvantages of Total Quality Management implementation in PT. XYZ

\section{Descriptive of Respondents}

The respondents in this study were employees at PT. XYZ with 180 respondents with characteristics of respondents based on gender, age, company origin, position, working period and work unit. Descriptive data characteristics of Respondents. The questionnaire has been disseminated, re-filled all and filled out so that 180 valid respondents can be obtained for further analysis. Questionnaire result obtained data on the composition of respondents based on the gender of the majority of men by $85,56 \%$ the average age of respondent age $\geq 35$ years of age of $57,22 \%$ Based on business unit of the company

\section{Confirmatory Factor Analysis (CFA) Test Result}

\section{$>$ Just In Time Variables}

shows that the majority of the company's origin respondents are from water pumps of $100,00 \%$. Characteristics according to the office show that the majority of respondents who filled out the questionnaire had a GC/Supervisor level position of $37,22 \%$, a staff level of $16,67 \%$, a Section Head level of $22.78 \% \%$ working period as a large respondent having a period of 5 to $<10$ Years as much as $48,89 \% \%$. Unit working respondents described that the majority of respondents $71,11 \%$ came from the production work unit, then quality Control section as $26,67 \%$.

\begin{tabular}{|c|c|c|c|c|}
\hline & & & $P$ & Estimate \\
\hline Minimum inventory & $<-$ & JIT & $* * *$ & .580 \\
\hline Improvement of factory layout & $<-$ & JIT & $* * *$ & .662 \\
\hline Limited number of suppliers & $<-$ & JIT & & 1.066 \\
\hline Flexible workforce & $<-$ & JIT & & 1.122 \\
\hline FW1 & $<-$ & Flexible workforce & & .622 \\
\hline FW2 & $<--$ & Flexible workforce & $* * *$ & .648 \\
\hline
\end{tabular}

Table 6:- Regression Weights and Standardized Weights Variable JIT 
Table 6 above shown that regression weight indicates that the probability value is limited number of suppliers dimensions, minimum inventory, improvement of factory, flexible workforce below 0.05 , then all dimensions are declared valid. Loading value of standardized estimate indicators FW1 (0.622), FW2 (0.648) against flexible workforce dimensions. Standardized output estimate of all dimensions improvement of factory (0.662), limited number of suppliers $(1,066)$, flexible workforce $(1,122)$, and minimum inventory (0.662) against JIT variables are all above 0.5 . Thus it shows that all of these dimensions can explain the JIT variable (Haryono, 2017; Ghozali, 2017). CFA test result data after it is deleted where each JIT variable along with its dimensions and indicators have a specific Standardized estimate value.

\section{$>$ TQM Variables}

\begin{tabular}{|c|c|c|c|c|}
\hline & & & $\mathrm{P}$ & Estimate \\
\hline Leadership & $<--$ & TQM & $* * *$ & .841 \\
\hline $\begin{array}{c}\text { Respect for } \\
\text { employees }\end{array}$ & $<--$ & TQM & $* * *$ & 1.024 \\
\hline $\begin{array}{c}\text { Relations with } \\
\text { suppliers }\end{array}$ & $<--$ & TQM & $* * *$ & .827 \\
\hline $\begin{array}{c}\text { Employee education } \\
\text { and training }\end{array}$ & $<--$ & TQM & $* * *$ & .838 \\
\hline Process improvement & $<--$ & TQM & $* * *$ & .863 \\
\hline Decision making & $<--$ & TQM & & .951 \\
\hline RE3 & $<--$ & $\begin{array}{c}\text { Respect for } \\
\text { employees }\end{array}$ & & .793 \\
\hline RE2 & $<--$ & $\begin{array}{c}\text { Respect for } \\
\text { employees }\end{array}$ & $* * *$ & .784 \\
\hline
\end{tabular}

Table 7:- Regression Weights and Standardized Weights variable TQM

Regression Weight Table 7 above shows that the probability value of all leadership dimensions, respect for employees, relation with suppliers, employee education and training, process improvement and decision making below 0.05 , then all dimension are declared valid. Loading value of standardized estimate indicator RE3 (0.793), RE2 (0.784) against respect for employees dimensions. Standardized output estimates of all leadership dimensions (0.841), respect for employees $(1,024)$, relation with suppliers (0.827), Employee education and training (0.838), process improvement $(0.863)$ and decision making (0.951) against TQM variables are all above 0.5 . Thus it shows that all of these dimensions can explain the TQM variable (Haryono, 2017; Ghozali, 2017). The data of the confirmatory factor analysis test after it is deleted where each TQM variable and its dimensions and indicators have a specific standardized estimate value.

The results of this study have implications on managerial policy and can be used by management in making company policies to produce a good JIT. From Table 6 it is known that flexible workforce dimensions $(1,122)$, limited number of suppliers $(1,066)$, improvement of factory (0.662), minimum inventory $(0.662)$ are the right way especially in the just in time section. Flexible workforce dimensions play an important initial role before the implementation process. Implementation of just in time at PT. XYZ's strength is in the flexible workforce dimension where the main focus is employees at PT. XYZ that can perform repair and maintenance machines (FW2), then special training for employees (FW1).

In this study, the success of just in time can be achieved through the flexible workforce process by performing repair and maintenance of the machine (FW2). The activity is to provide repair training, machine maintenance and skills in measuring product dimensions. Repair training aims to speed up the repair time of the machine so that production does not experience delays. Maintenance of the machine is carried out by carrying out the machine seiso and total preventive maintenance (TPM) periodically. This is done so that the machine does not run into any problems during production. In addition, the success of just in time on flexible workforce is special training for employees (FW1). The way it is done gives training care to the products it produces. Each employee is responsible for the resulting output. Special training for employees continues to be conducted regularly. Training and improving skills for employees in their respective workplaces to continue to pay attention to problem solving and process improvement, be it improved process time or productivity and improving quality to avoid problems.

The results of this study also have implications on managerial policy and can be used by management in determining company policies to produce good total quality management (TQM). From Table 7 it is known that the dimensions of respect for employees $(1,024)$, decision making (0.951) process improvement (0.863), leadership (0.841), employee education and training (0.838) and relation with suppliers (0.827) are the right ways especially in the total quality management section and holding an important initial role before the implementation process. Implementation of total quality management in PT. XYZ's strength is in the dimension of respect for employees where the main focus is employees at PT. XYZ that can provide information in product assessment (RE3), then employee support (RE2). In this study, the success of TQM can be achieved through the process of respect for employees by providing information in product assessment and support to employees.

The activity carried out towards providing information in product assessment is to survey employees about the product, provide claim market information and feedback the market that occurs in the market so that employees know the value of the products produced. Before launching a new product, employees are involved in a product survey to assess customer feasibility and satisfaction, assess the design and quality of the product, including assessing the attractiveness of the product and the advantages of the product launched. The quality assurance (QA) section periodically monitors employee attitudes and satisfaction. This can be done by holding a formal survey every year. Activities involved and supporting employees in providing 
trainings both internal and external to improve the employee's ability and provide promotions and bonuses to employees thus increasing motivation towards the employee himself. PT. XYZ encourages employees to innovate and creativities.

\section{CONCLUSIONS AND SUGGESTIONS}

\section{A. Conclusion}

Based on the results of data analysis, this study can be drawn the following conclusions:

$>$ Qualitative analysis of the evaluation of the implementation of JIT shows that: PT. XYZ has implemented the method just in time against limited number of suppliers, minimum inventory, improvement of factory layout, set-up time reduction, integrated quality control and flexible workforce, but still encountered few constraints in the application of just in time material import i.e. delay in material import due to weather factors and found constraints especially inventory for imported materials is difficult to minimize.

$>$ Qualitative analysis of the evaluation of the implementation of TQM shows that: PT. XYZ has conducted the implementation of total quality management especially towards customer focus, leadership, respect for employees, process approach and employee education and training, continual improvement, factual approach to decision making and mutually beneficial supplier relationship.

$>$ The results of this study have implications on managerial policy and can be used by management in making company policies to produce just in time. The standardize estimated value is in the flexible workforce dimension of 1,122 , which is the right way especially in the just in time section. Flexible workforce dimensions play an important initial role before the implementation process, where the main focus is employees. PT. XYZ can perform repair and maintenance machines (FW2), and then specialized training for employees (FW1). In this study, the success of JIT can be achieved through the flexible workforce process by performing repair and maintenance of the machine (FW2).

$>$ The results of this study also have implications on managerial policy and can be used by management in determining company policies to produce good total quality management. This is evidenced by the test results using confirmatory factor analysis of its dimensions. The standardize estimated value is in the respect for employees dimension of 1,024 which is the right way, especially in the total quality management section and plays an important initial role before the implementation process, where the main focus is employees at PT. XYZ that can provide information in product assessment (RE3), then employee support (RE2).

\section{B. Suggestion}

Suggestions that the author can give in connection with the results of the research that has been done are as follows:

$>$ Seeing so much benefit from the implementation of just in time should the management of PT. XYZ considers eliminating obstacles faced in the application of just in time such as delay in material import due to weather factors, inventory for raw material import is difficult to minimize, rotor assembly layout because lay out rotor is located in different building, sudden model change, product damage is required control and monitoring of elements just in time strictly so that production achievement and productivity can reach $100 \%$.

$>$ The Company must continue to evaluate the implementation of the system just in time and total quality management in the company to compare the company's performance achieved from year to year and in order to improve the quality of production results.

$>$ It is necessary to do more research by retesting in different industry groups, not only manufacture industry field for example doing research on service companies, so that it can be known differences and similarities with the results of this study.

$>$ Research using case studies that have limitations that among others in the form of results obtained become less objective.

\section{REFERENCES}

[1]. Amelia Natasya Abdul Wahaba, Muriati Mukhtara, and Riza Sulaimanb. 2013. “A Conceptual Model of Lean Manufacturing Dimensions". The 4th International Conference on Electrical Engineering and Informatics.

[2]. Akhmad Jakfar, Wahyu Eko Setiawan, Ilyas Masudin, 2015. "Reducing Waste by Using Lean Manufacturing Approach".

[3]. Achmad Misbah, Pratikto, Denny Widhiyanuriyawan, 2015, "Efforts to Minimize Non Value Added Activities of Furniture Products in the Application of Lean Manufacturing Method".

[4]. Belinda Halim and Hendro Lukman, 2019, "Evaluation of ISO Implementation in PT Information System. Sinar Syno Kimia", Journal of Multiparadigma Accounting, Vol. 1, No. 3, Pp. 1003-1012.

[5]. Christina E. Shalley, 2017, "Creativity and the Management of Technology: Balancing Creativity and Standardization".

[6]. Ferdinand, Augusty. (2014). Management Research Method. Issue 5. Undip Publishing Agency. Semarang.

[7]. Hagi S, 2017, "Advantages and disadvantages of Total Quality Management And Six Sigma", http://hagisantoro.blogspot.com/2017/07/kelebihan-dan kekurangan-total-quality.html. July 12, 2017. 
[8]. Halim B, Lukman H, 2015, "Evaluation of ISO Application in PT Information System. Sinar Syno Kimia", Journal of Multiparadigma Accounting, Volume I No. 3/2019 P. 1003-1012.Hadioetomo. (2009). "Effect of JIT implementation on the Company's Performance and Competitive Advantage". Journal of Accounting Studies, Volume 4, Number 2, December 2009: 104-113.

[9]. Hensen, Don R. and Maryana M. Mowen. 2013. Managerial Accounting. Issue Eight. Book 2. Jakarta: Salemba Empat.

[10]. Ilyas Masudin, Mohammed S. Kamara, 2016, Impact of Just-In-Time, Total Quality Management and Supply Chain Management on Organizational Performance: A Review Perspective.

[11]. ISO, 2008.ISO. ISO 9001 Geneva: Quality Management System-Requirements.

[12]. James and Womack a.l. 1997. Lean Thinking. According to Hines \& Rich". Ghozal I. 2017. "Structural Equation Model, Concept and Application with Amos 24 Update Bayesian SEM Program". Undip-Publishing Agency. Issue 7.

[13]. Kusumawati, Ratna, 2009. Sudi Just in Time To Improve The Productivity Performance of The Company,. Journal of Economics and Business, Volume 4, No. 08.

[14]. Linda Santioso and Cynthia Maharani, 2015, "Analysis of the Influence of Total Quality Management and Just In Time Implementation on Manufacturing Industry (Empirical Studies at Manufacturing Companies in Bogor and Tanggerang)", Journal of Economics/Volume XX, No. 03, November 2015: 371386.

[15]. Marida Suneth, 2016, "Application of Just In Time System in Improving Company Productivity In PT. Create Sinar Perkasa Concrete in Makassar".

[16]. Maulana, Dede and Sulistyowati, Niken (2020). The Influences of Occupational Safety and Health, NonPhysical Work Environment on Employee's Productivity at PT XYZ. International Journal of Innovative Science and Research Technology (IJISRT) Volume 5, Issue 1, January - 2020

[17]. Murni, 2018, "Implementation of Total Quality Management (TQM) in An Effort to Improve the Quality of Pilgrim Service in the Ministry of Religious Affairs of Jeneponto Regency".

[18]. Novianti Ika Sari, N.I, and Trijoyo JD, 2012, Confirmatory Factor Analysis to Measure Unidimensional Environmental Management Performance Indicators in Public Survey Autonomy Award Jawa Pos Institute Of Pro Autonomy Year 2011, JURNAL SAINS DAN SENI ITS . Vol. 1. No. 1, p. 17.

[19]. Padmantyo S, Tikarina Q.N, 2018 " EOQ and JIT : Which is more Appropriately Applied Manufacturing Copany?", Proceedings: The National Conferences Management and Business (NCMAB).

[20]. Rafiq M, 2017, "Just In Time Analysis to improve compatitive advaantage on Aulia Aluminum".
[21]. Rishna Maulina, 2019, "Manufacturing Industry Challenges \& How to Overcome Them" Published 22 May 2019, IN Business, https://www.jurnal.id/id/blog/tantangan-industrimanufaktur-dan-cara-mengatasinya/ 7.

[22]. Rizal Rahmat Darmawan, June 2016, "Analysis of The Total Value of Productivity Factors in The Manufacturing Industry in East Java".

[23]. Rajnoha, R., Dobrovič, J., Gálová, K. (2018), ”The use of Lean Methods in central Eastern European Ountries : The Case of Czech and Slovak Republic".

[24]. Rahayu S, 2020, "Research Gap; These types of Research Gap", accessed january 21, 2020, https://hayumenulis.blogspot.com/2020/01/research-gap.html

[25]. Simamora, Henry. 2012. Management Accounting. Third edition. Star Gate Publisher, Riau Islands Province.

[26]. Teaching Staff. ( 2018). Thesis Preparation Guidance Book. Issue 12. Postgraduate Program of Master of Management Program. Jakarta.

[27]. Sumartono and Petrus Megu. (2014). "Empirical Lean Manufacturing Study in Building Competitiveness".

[28]. Sri Padmantyo, Qori Nur Tikarina, 2018, "EOQ and JIT : Mama Yang Lebuh Appropriately applied Perushaan Manufaktur ?". Proceedings: Empowerment and Strengthening of Business Competitiveness in the Digital Age, ISSN: 2621 - 1572, The National Conferences Management and Business (NCMAB)..

[29]. Sik Sumaedi A, Medi Yarmen, 2015, "The Effectiveness of ISO 9001 Implementation in Food Manufacturing Companies: A Proposed Measurement Instrument".

[30]. Trismi Ristyowati, Ahmad Muhsin, and Putri Puji Nurani. 2017. "Minimasi Waste in Production Process with Lean Manufacring Concept"

[31]. Yusuf, Muri.2015. Research Method: Quantitative, Qualitative and Joint Research, First Edition, 2nd Printing, Publisher: PT. Prenadamedia Group.

[32]. Wahyu Adrianto, Muhammad Kholil, 2015, Analysis of Lean Pruduction Process Implementation to Reduce Lead Time Process Maintenance Engine ( Study Case PT. GMF Aeroasia).

[33]. Wisner, Tan and Leong. 2012. "Principles of Supply Chain Management A BALANCED APPROACH". 3e CHAPTER 8: Process Management : Just-in Time and Total Quality Management.

[34]. Wijaya, Eri and Niken Sulistyowati, Niken (2019) The Effect of Application of Hospital Management Information Systems on Operational Performance Through User SatisfactionMaster European Journal of Business and Management Vol.11, No.36 - 2019.

[35]. Wulandari D, Retnani E.D, 2017, "Application of Motode Just In Time To Cost Efficiency of Raw Materials PT. Harmonize Invitation", Journal of Accounting Science and Research, Volume 6, Number 9, September 2017. 